\title{
Heterogeneity in glutamic acid decarboxylase expression among single rat pancreatic beta cells
}

\author{
M. C. Sánchez-Soto, M. E. Larrieta, R. Vidaltamayo, M. Hiriart \\ Department of Biophysics, Institute of Cell Physiology, National Autonomous University of Mexico, Mexico
}

\section{Abstract}

Aims/hypothesis. An isoform of glutamic acid decarboxylase, (GAD)65 has been identified as a pancreatic beta-cell autoantigen in Type I (insulin dependent) diabetes mellitus. We investigated the expression of GAD isoforms among single rat beta cells in culture, under different conditions and the correlation between GAD65 expression and insulin secretion-rate.

Results. Independent of culture conditions, $100 \%$ of fresh and cultured beta cells express GAD67. In contrast, considerable heterogeneity in GAD65 expression among single beta cells was observed. After 2 days in culture in $2.6 \mathrm{mmol} / 1$ glucose, only $24 \%$ of the beta cells express GAD65. This percentage increases to $39 \%$ in $5.6 \mathrm{mmol} / \mathrm{l}$ glucose and to $54 \%$ and $56 \%$ in $11.6 \mathrm{mmol} / \mathrm{l}$ and $20.6 \mathrm{mmol} / \mathrm{l}$ glucose, respectively. Moreover, reducing glucose concentration from 11.6 to $2.5 \mathrm{mmol} / \mathrm{l}$ for 2 days, reduces GAD65 expression by nearly $30 \%$. After 11 days in culture with $11.6 \mathrm{mmol} / \mathrm{l}$ glucose, $50 \%$ of beta cells continue expressing GAD65, this percentage is further increased to nearly $75 \%$ by including either nerve growth factor or dibutyryl cyclic AMP or both in the culture medium. When beta cells are challenged for $1 \mathrm{~h}$ with $20.6 \mathrm{mmol} / 1$ glucose, $67 \%$ respond forming insulin-immunoplaques. More than two-thirds of insulin-secretors are GAD65-positive, in contrast to only $11 \%$ of the non-secreting cells. Moreover, $87 \%$ of beta cells that have a high insulin secretory rate express GAD65.

Conclusion/interpretation. These results show that the most active beta cells, which secrete more insulin, also express GAD65 and that manipulating extracellular glucose may modify the expression of the enzyme and possibly the autoimmune attack in Type I diabetes. [Diabetologia (1999) 42: 1086-1092]

Keywords GABA, GAD65, GAD67, pancreatic beta cells, insulin secretion, reverse hemolytic plaque assay.
Pancreatic beta cells contain the enzyme glutamic acid decarboxylase (GAD) that catalyses the biosynthesis of the neurotransmitter $\gamma$-aminobutyric acid (GABA) $[1,2]$. Two non-allelic genes probably de-

\section{Received: 28 December 1998 and in revised : 05 May 1999}

Corresponding author: Dr. M. Hiriart, Department of Biophysics, Instituto de Fisiología Celular, A.P. 70-253, Universidad Nacional Autónoma de México, 04510 México D.F, Mexico Abbreviations: GAD, Glutamic acid decarboxylase; GABA, $\gamma$ amino butyric acid; NGF, nerve growth factor; dbcAMP, dibutyryl-cAMP; RHPA, reserve hemolytic plaque assay; SP, small plaque-forming cells; LP, large plaque-forming cells. rived from a common ancestral gene encode GAD. The two GAD isoforms, named GAD65 and GAD67 according to their approximate molecular weight in $\mathrm{kDa}$, share a similar structure, except in the first 95 amino acids [3]. Despite their homology, there are structural and functional differences between them that are reflected by their intracellular compartmentalization and the degree of saturation with the coenzyme pyridoxal phosphate (PLP) [2-4].

Although the physiological significance of GAD and GABA in beta-cell function is not entirely clear, the presence of antibodies directed against GAD65 have been implicated in the pathogenesis of Type I (insulin-dependent) diabetes mellitus and Stiff-Man 
syndrome [5]. The expression of GAD antibodies in a high percentage of prediabetic patients has been reported, suggesting that humoral immunity directed against GAD might be a predisposing factor to development of this disease [4-7]. In recent onset Type I diabetic patients, the frequency of GAD65 antibodies is $82 \%$ but after a median duration of 21 years of Type I diabetes the high antibody prevalence decreases to $32 \%$ [7].

The manner in which GADs and GABA are regulated in the pancreatic islets is controversial. Glucose stimulates GABA secretion from the pancreatic $\beta$ TC6 cell line [8]. GABA content and release by normal rat beta cells are however, dependent on glutamine concentration and glutamine-induced GABA release is inhibited by high glucose concentrations [9].

In vitro modulation of GAD expression by high extracellular glucose concentration in islets has been described. One study describes an increase in GAD65 expression [10] and another one of both GAD isoforms [11] in islets cultured under hyperglycaemic conditions, suggesting that GAD expression is correlated with an increased functional state of beta cells.

All these studies on GAD expression were done in pancreatic islets or in the whole pancreas; nevertheless, single beta cells show considerable heterogeneity [12-18]. The existence of functional subpopulations of adult rat beta cells has been shown. In vitro characterizations of functional subpopulations have shown differences in:

1. Glucose sensitivity among single beta cells that result in the recruitment of previously silent cells to insulin secretory-activity when extracellular glucose concentration is increased [13-15].

2 . Insulin secretion rate, which means that in response to fixed glucose stimulation, one functional subpopulation secretes more insulin than the other [13-15]. This property is also evident with other secretagogues like carbachol [16] and amino acids [17]. 3 . Sensitivity of the beta cells to diabetogenic agents and their defence mechanisms after a cytotoxic exposure [18].

Other factors possibly regulate GAD expression in normal beta cells. We characterized the effects of nerve growth factor (NGF) and dibutyryl-cAMP (dbcAMP) on beta-cell morphology and insulin secretion [19]. We found that after 11 days in culture under these conditions, all beta cells retained their immunoreactivity to insulin and GABA. Insulin secretion of dbcAMP-treated cells was 2.5 -fold higher than in control cells, whereas NGF-treated cells were able to discriminate between different glucose concentrations, a property lost in control cells with time in culture. It has been shown in the insulinoma cell line INS-1 that NGF potentiates glucose induced-insulin secretion by activating the mitogen-activated protein kinase [20]. We have also found that beta cells synthesize and also secrete NGF in response to glucose [21]. If the expression of GAD is correlated with the metabolic state of beta cells, it is then possible that dbcAMP and NGF could increase this expression.

Identification of the traits, which make some beta cells more susceptible to diabetogenic conditions, is important to understand the clinical pathological findings in Type I diabetes. It is not known if GAD distribution is homogenous among beta cells. In this study, we analysed GAD65 and GAD67 expression in single rat beta cells under different conditions: (1) fresh and cultured cells for 2 days in different glucose concentrations (2) cultured cells for 11 days in $11.6 \mathrm{mmol} / \mathrm{l}$ glucose, in the presence of either NGF or dbcAMP or both (3) GAD65 expression in cells cultured for 2 days in 11.6 or $2.5 \mathrm{mmol} / \mathrm{l}$ glucose and sequentially for 2 more days in 2.5 and $11.6 \mathrm{mmol} / \mathrm{l}$ glucose, respectively.

We also analysed the expression of GAD65 by the functional subpopulations of beta cells.

\section{Materials and methods}

Reagents were obtained from the following sources: collagenase type IV from Worthington (Freehold, N.J., USA); guineapig insulin antisera for reserve haemolytic plaque assay (RHPA) from Arnel (New York, N.Y., USA); bovine serum albumin (BSA, fraction V), chromium chloride, staphylococcal protein A, HEPES, glucose, Ficoll, NGF 2.5 s, dbcAMP, trypsin, poly-L-lysine hydrobromide $(\mathrm{MW}>380,000)$, RPMI 1640 salts, 3-3' diaminobenzidine tetrahydrochloride and tissue culture dishes (Corning, Cat. No. 25000-35) from Sigma Chemical, Co. (St. Louis, Mo., USA); fetal bovine serum, guinea-pig complement, Hanks' balanced salt solution (HBSS) and penicillin-streptomycin solutions from GIBCO (Grand Island, N.Y., USA); biotin/Avidin Vectastain ABC kit from Vector Laboratories (Burlingame, Calif., USA); CY5 from Zymed (San Francisco, Calif., USA).

Dr. A. Tobin kindly provided GAD 65 (GAD6) and GAD67 (K2) antisera. The latter is an antiserum and GAD6 is a monoclonal antibody. The specificity of both antisera has been extensively characterized $[22,23]$.

Animals and pancreatic islet cell cultures. Animal care was in accordance with the NIH Guide for the Care and Use of Laboratory Animals (National Institute of Health Publication No. 85-23, revised, 1985). Young adult male Wistar rats, (200-250 $\mathrm{g}$ ), were obtained from the local animal facility, maintained in a 14-h light (0600-2000 hours), 10-h dark cycle and allowed free access to standard laboratory rat chow and tap water.

Adult pancreatic islet cells were isolated as described previously [19]. Briefly, pancreatic islets were separated from the acinar tissue by collagenase digestion and a Ficoll gradient centrifugation; clean islets were then handpicked. Dissociation of the cells was achieved by incubating the cells in a shaker bath for $10 \mathrm{~min}$ at $37^{\circ} \mathrm{C}$ in calcium-free Hanks' balanced salt solution, with $15.6 \mathrm{mmol} / \mathrm{l}$ glucose, $0.5 \% \mathrm{BSA}$ and $0.01 \%$ trypsin, followed by mechanical disruption. 
Isolated islet cells were cultured in RPMI 1640, supplemented with $10 \%$ fetal bovine serum, $100 \mathrm{U} / \mathrm{ml}$ penicillin, $100 \mu \mathrm{g} / \mathrm{ml}$ streptomycin and $0.25 \mathrm{mg} / \mathrm{ml}$ fungizone, on standard tissue culture dishes. Cells were cultured: a) for 2 days in RPMI-1640 with different glucose concentrations (mmol/l): $2.5,5.6,11.6,20.6$; or b) for 11 days in regular RPMI-1640 (with $11.6 \mathrm{mmol} / \mathrm{l}$ glucose, control conditions) or with either NGF $(50 \mathrm{ng} / \mathrm{ml})$ or dbcAMP $(5 \mathrm{mmol} / \mathrm{l})$ or both, changing the medium every other day; or c) cells were cultured for two days in RPMI 1640 with 11.6 or $2.5 \mathrm{mmol} / \mathrm{l}$ glucose and sequentially for other two days in 2.5 and $11.6 \mathrm{mmol} / 1$ glucose, respectively. Cultures were maintained at $37^{\circ} \mathrm{C}$, in a humidified incubator $\left(5 \% \mathrm{CO}_{2}\right.$ in $95 \%$ air).

Reverse Haemolytic Plaque Assay (RHPA). Insulin secretion from individual beta cells was analysed after two days in culture, under different experimental conditions, with a RHPA [24], as previously described [25]. Briefly, islet cells were detached from culture dishes by incubating them for $10 \mathrm{~min}$ in calcium-free Hanks' solution, with $15.6 \mathrm{mmol} / \mathrm{l}$ glucose and $0.5 \%$ BSA. Equal volumes of cells were mixed with protein A-coated sheep erythrocytes, introduced into Cunningham chambers treated with poly-L-lysine to promote cell attachment and incubated for $45 \mathrm{~min}$. Then the chambers were rinsed and filled with Hanks' balanced salt solution which contained $20.6 \mathrm{mmol} / 1$ glucose and incubated for an hour in the presence of insulin antiserum. The monolayer was further incubated for $30 \mathrm{~min}$ with guinea-pig complement. Insulin released during the incubation time with the insulin antiserum was shown by the presence of haemolytic plaques (immunoplaques) around the secretory cells, which result from the complement-mediated lysis of erythrocytes bearing insulin-anti-insulin complexes bound to protein A.

We measured the size of immunoplaque by projecting the image of the cell on a monitor attached to a video camera and a Nikon Axiophot inverted microscope(Nikon, Tokyo, Japan), with the aid of the JAVA video analysis software (Jandel Scientific, Version 1.40, Corte Madeira, Calif., USA). Immunoplaque size was expressed as area. At least 50 cells were measured for each experimental condition. We also counted the number of cells that formed immunoplaques and these results were expressed as the percentage of insulin plaque-forming cells. At least 100 cells were counted per experimental condition. All the experiments were carried out in duplicate.

A frequency distribution of immunoplaque areas was constructed to identify functional populations of beta cells. According to the size of immunoplaques formed by the cells, we classified them as follows: small plaque-forming cells (SP) diameter of immunoplaque $2000 \mu \mathrm{m}^{2}$ or less and large plaque forming cells (LP), diameter more than $2000 \mu \mathrm{m}^{2}$.

Immunocytochemistry. For laser confocal analysis, fresh single cells were processed and incubated overnight with a mouse anti-GAD65 antibody, a rabbit anti-GAD67 and guinea-pig anti-porcine insulin antibody (Incstar, Stillwater, Mich., USA), as recommended by the supplier's technical bulletins. After this incubation, a second CY5-conjugated (excitation = $650 \mathrm{~nm}$, emission $=670 \mathrm{~nm}$ ) goat anti-mouse IgG antibody was added in the case of GAD65. In the case of GAD67 detection, a CY5-conjugated goat anti-rabbit IgG antibody was used. Finally, a FITC-conjugated goat anti-guinea-pig IgG antibody (excitation $=494 \mathrm{~nm}$, emission $=520 \mathrm{~nm}$ ) was used for insulin detection. Cells were observed under a confocal microscopy using the red channel for CY5 and the green channel for FITC. We avoided spurious labelling of cells with the second antibody by using antibodies generated in different species.
For other experiments, the ABC method was carried out on cultured cells to detect GAD65 or GAD67, using 3,3'-diaminobenzidine as the final substrate, to form a brown reaction product. After this procedure, double antigenic staining to detect insulin was accomplished, using a secondary FITC-labelled antibody. Finally in other experiments, ICC against GAD65 and GAD67 was done on beta cells identified with the RHPA.

In all cases, dilution of antisera was as follows: insulin 1:4000, GAD65 1:250, GAD67 1:5000. Specificity of all stainings was assessed carrying out the whole procedures without the primary antibodies. In such cases, no positive reactions were observed.

At least 50 cells were measured for each culture dish and all experiments were done in duplicate. In any given condition, a minimum of three separate cultures were evaluated.

Statistical analysis. Significant differences between data were evaluated by analysis of variance (ANOVA), followed by Fisher's multiple range test, using the Number Cruncher Statistical System (NCSS, 4.2, Dr. J.L. Hintze, Kaysville, Utah, USA, $1983)$. All results are expressed as mean values ( \pm SEM), $n$ denotes the number of cells studied or of experiments.

\section{Results}

The expression of GAD65 and GAD67 in fresh and cultured beta cells. The expression of GAD65 and GAD67 by single beta cells fresh or cultured for 2 days was examined using immunofluorescence. Figure 1 shows fresh islet cells. A double labelling technique was used to identify beta cells with a FITC probe for insulin, (green staining) and a CY5 probe for either GAD65 or GAD67 (red staining).

Only $33 \%$ of fresh beta cells express GAD65 (Fig.2). The arrows in Fig. 1A show beta cells that do not express GAD65; no insulin-negative, GAD65-positive cells were observed. Almost all freshly isolated beta cells express GAD67 (Figs. 1C and $\mathrm{D}$ and 2 ), and nearly $13 \%$ of GAD67 positive cells are negative to insulin.

After 2 days in culture in $11.6 \mathrm{mmol} / \mathrm{l}$ glucose, all beta cells express GAD67 and nearly $50 \%$ of them also express GAD65; there were no further changes in these percentages after 11 days. When cells were cultured for 11 days in the presence of either NGF or dbcAMP or both for maximum stimulation, the percentage of beta cells expressing GAD65 increases to nearly $80 \%$ (Fig. 2).

Expression of GAD65 in beta cells is glucose-dependent. After culturing islet cells for 2 days in a low glucose concentration $(2.5 \mathrm{mmol} / \mathrm{l})$ only $24 \%$ of beta cells are positive to GAD65. When glucose concentration in the medium was increased to $5.6 \mathrm{mmol} / \mathrm{l}$, $11.6 \mathrm{mmol} / \mathrm{l}$ and $20.6 \mathrm{mmol} / \mathrm{l}$ glucose, the percentage of GAD65 positive beta cells increased to $39 \%$, $54 \%$ and $56 \%$, respectively (Table 1 ). The expression of GAD67 is not dependent on glucose concentration in the culture medium because nearly all beta 


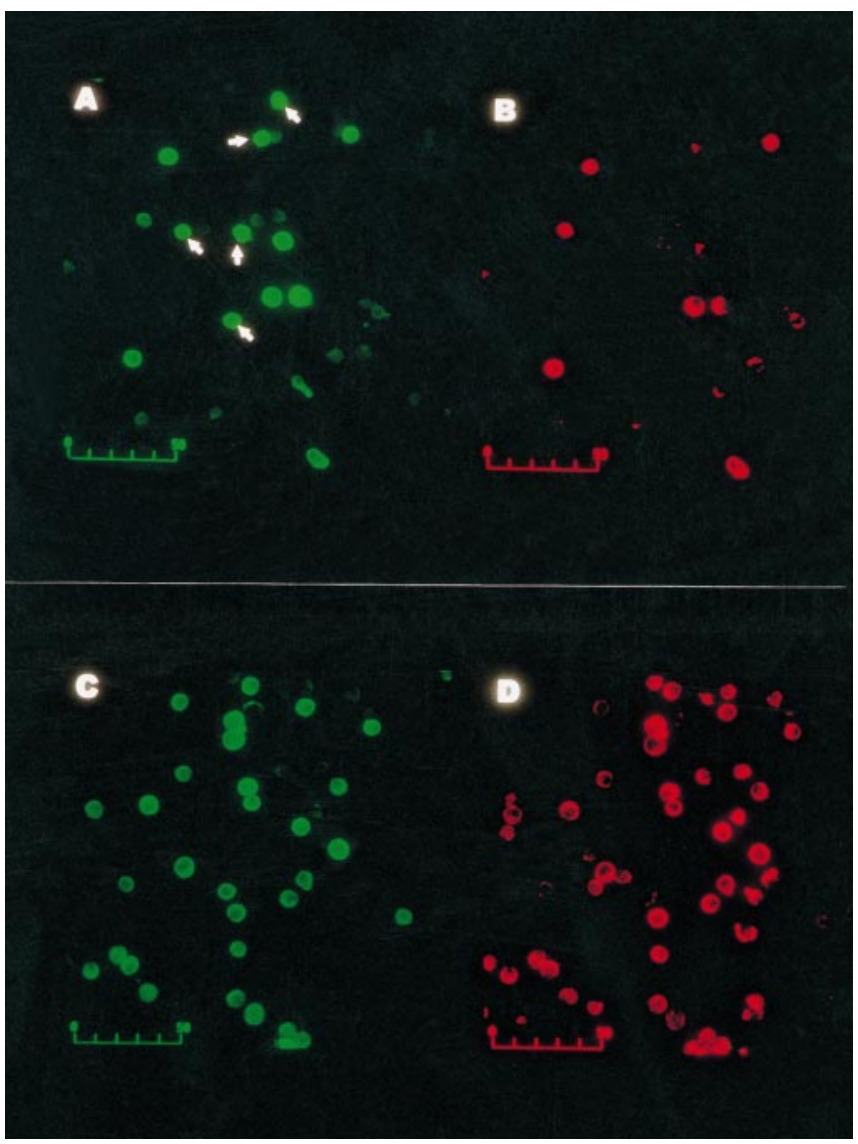

Fig. 1A-D. Expression of GAD65 and GAD67 in freshly isolated beta cells. A, B Cells were double-stained for insulin (green staining, A) and GAD65 (red staining, B). Insulinpositive but GAD65-negative cells are indicated by arrows. C, D Cells were double-stained for insulin (green staining, C) and GAD67 (red staining, D) In this section, nearly $80 \%$ of cells are double positive to GAD67 and insulin and nearly $15 \%$ of fresh cells express only GAD67. Bar $=50 \mu \mathrm{m}$

cells were stained for this enzyme in every culture condition.

To explore glucose-dependence in GAD65 expression and the reversibility of the process, islet cells were cultured for 2 days in $11.6 \mathrm{mmol} / \mathrm{l}$ glucose and changed sequentially to $2.5 \mathrm{mmol} / \mathrm{l}$ glucose for 2 days. In these conditions the percentage of GAD65 positive cells decreased from $47 \%$ to $32 \%$ (Table 2). By contrast, when cells were cultured for 2 days in $2.5 \mathrm{mmol} / \mathrm{l}$ glucose and changed to $11.6 \mathrm{mmol} / \mathrm{l}$ glucose, the percentage of GAD65-positive cells increased from $26 \%$ to $46 \%$.

Expression of GAD65 by insulin secreting cells. Insulin secretion by individual beta cells, previously cultured for $48 \mathrm{~h}$ with $11.6 \mathrm{mmol} / 1$ glucose, in response to a $20.6 \mathrm{mmol} / \mathrm{l}$ glucose challenge for $1 \mathrm{~h}$ in the presence of an insulin antiserum was measured with RHPA. At the end of the assay, cells were fixed and the expression of GAD65 was determined by immu-

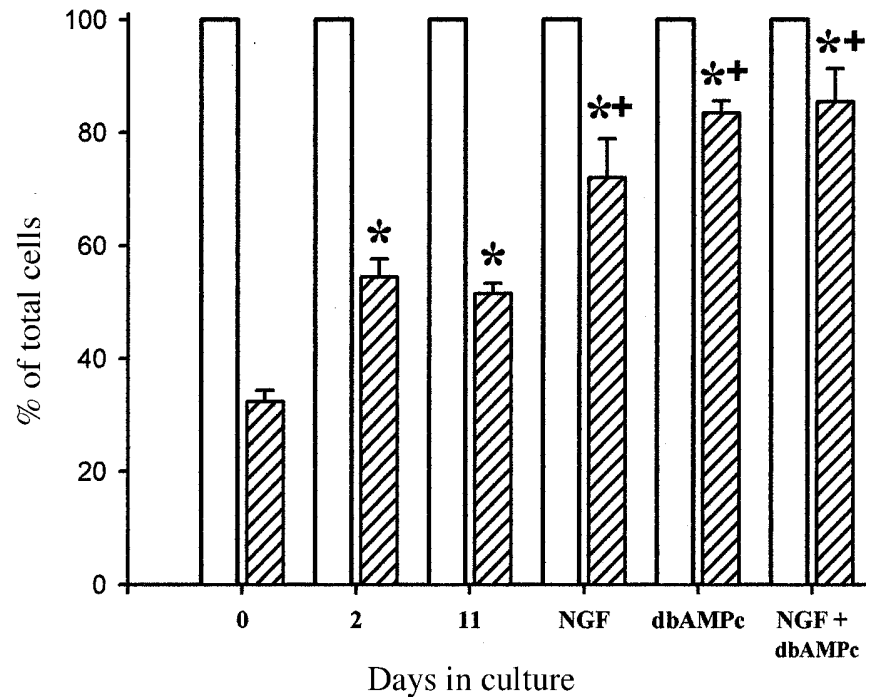

Fig. 2. Expression of GAD65 and GAD67 in single beta cells. The highest expression of GAD65 was observed in cells treated with NGF (50 ng/ml) and dbcAMP (5 mmol/l). Each data point represents the mean \pm SEM of 4 separate experiments in duplicate. * Denotes significance level for fresh beta cells, $p<0.01$. + Denotes significance level for beta cells cultured for 11 days, $p<0.01$. $\square$ GAD67; $\mathbb{G A D 6 5}$

Table 1. GAD65 and GAD67 expression on different extracellular glucose concentrations

\begin{tabular}{lcccc}
\hline Glucose & $2.5 \mathrm{mmol} / 1$ & $5.6 \mathrm{mmol} / \mathrm{l}$ & $11.6 \mathrm{mmol} / \mathrm{l}$ & $20.6 \mathrm{mmol} / \mathrm{l}$ \\
\hline GAD67 & $97.0 \pm 1.9$ & $97.0 \pm 1.5$ & $97.7 \pm 1.8$ & $97.7 \pm 1.8$ \\
GAD65 & $24 \pm 1.6^{\mathrm{a}}$ & $39 \pm 4.5^{\mathrm{a}}$ & $54 \pm 3.2^{\mathrm{a}}$ & $56 \pm 8.3^{\mathrm{a}, \mathrm{b}}$ \\
\hline
\end{tabular}

Each data point represents the mean \pm SEM of 4 separate experiments in duplicate.

${ }^{a}$ Denotes significance level for beta cells cultured in $2.5 \mathrm{mmol} / \mathrm{l}$ glucose. ${ }^{\mathrm{b}}$ Denotes significance level for beta cells cultured in $5.6 \mathrm{mmol} / \mathrm{l}$ glucose,$p<0.01$

Table 2. Effect of changing glucose concentration in culture medium on GAD65 expression by islet-cells

\begin{tabular}{ll}
\hline Glucose $(\mathrm{mmol} / \mathrm{l})$ & \% of GAD 65 $(+)$ cells \\
\hline $11.6^{\mathrm{a}}$ & $47 \pm 8$ \\
$2.5^{\mathrm{a}}$ & $26 \pm 8.5$ \\
$11.6 \rightarrow 2.5^{\mathrm{b}}$ & $32 \pm 4^{\mathrm{c}}$ \\
$2.5 \rightarrow 11.6^{\mathrm{b}}$ & $46 \pm 0.4^{\mathrm{c}}$
\end{tabular}

a Incubation time 4 days, ${ }^{\mathrm{b}}$ incubation time 2 days sequentially at each concentration. After 4 days in culture, cells were fixed and the percentage of GAD65 positive cells was measured by immunocytochemistry. Data point is the mean \pm SEM of 3 separate experiments in duplicate. ${ }^{\mathrm{c}}$ Denotes significance level for control cells, $p<0.05$, paired Student's $T$ test

nocytochemistry in the single beta cells identified by insulin immunoplaque.

In the presence of $20.6 \mathrm{mmol} / 1$ glucose, $67 \%$ of total cells formed insulin immunoplaques (insulin-secreting cells) and nearly two-thirds of them express GAD65. On the other hand, of the total cells that 


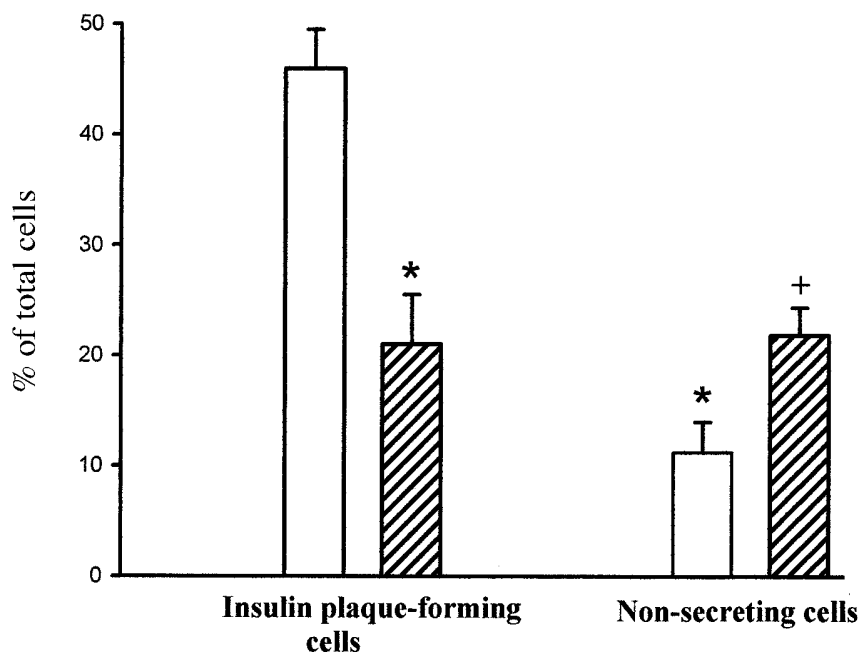

Fig.3. Expression of GAD65 in active insulin secretors. Islet cells were cultured for 2 days and insulin secretion by single beta cells was measured by RHPA, by incubating the cells with an insulin antiserum for 1 hour in the presence of $20.6 \mathrm{mmol} / \mathrm{l}$ glucose. At the end of RHPA, cells were fixed and immunocytochemistry detected the expression of GAD65. Each data point represents the mean \pm SEM of 4 separate experiments in duplicate. * Denotes significance level for insulin immunoplaque-forming cells that are positive to GAD65; + denotes significance level for non-secreting cells that are positive to GAD65, $p<0.01$. $\square$ GAD65 (+) CELLS; MGAD 65 (-) CELLS

Table 3. Expression of GAD65 in beta-cell functional-subpopulations

\begin{tabular}{lll}
\hline $\begin{array}{l}\text { Functional } \\
\text { subpopulation }\end{array}$ & $\begin{array}{l}\text { \% of insulin-immuno- } \\
\text { plaque forming-cells }\end{array}$ & $\begin{array}{l}\text { \% of GAD65 (+) cells } \\
\text { in each subpopulation }\end{array}$ \\
\hline \% of SP cells & $40 \pm 5$ & $63 \pm 2$ \\
$\%$ of LP cells & $54 \pm 9$ & $87 \pm 1$ \\
\hline
\end{tabular}

Immunoplaque area frequency distribution of GAD65-positive cells and GAD65-negative cells was constructed with data pooled from 3 separate experiments by duplicate

did not form insulin immunoplaques, $11 \%$ were positive for this enzyme and $22 \%$ were negative for GAD65 (Fig. 3). We do not know if all of the non-secretors, GAD65-negative cells are beta cells or another type of islet cell but we can estimate that at least $5 \%$ of them are beta cells.

Distribution analysis of insulin immunoplaque areas showed a bimodal distribution for GAD65-positive beta cells that corresponds to small plaque-forming cells and large plaque-forming cells. Half of the insulin secreting cells in $20.6 \mathrm{mmol} / \mathrm{l}$ glucose are LP cells. It is important to note that LP cells have the highest hormone secretion-rate and are responsible for $75 \%$ of the insulin secreted [13]. Nearly $85 \%$ of LP cells are positive to GAD65, indicating its expression is linked to the most active beta-cell subpopulation (Table 3).

\section{Discussion}

Functional and structural heterogeneity among beta cells has been shown in different in-vitro and in-vivo studies [26]. In addition, heterogeneity among betacell destruction in insulin-dependent diabetic patients has been detected; although the majority of beta cells were destroyed, those that survived remained healthy and had a dense insulin immunoreactivity [18]. Identification of the traits, which make some beta cells more susceptible to diabetogenic conditions, would be important to understand the clinical pathological findings in Type I diabetes.

The antigen GAD65 has been identified as being expressed by beta cells, to which autoantibodies are generated leading to beta-cell destruction, preceeding onset of Type I diabetes and in its early stages [4-7]. In this study, we show heterogeneity in GAD65 expression among single rat beta cells, related to the metabolic conditions of the cells.

We found that although nearly all the fresh beta cells express GAD67, only $33 \%$ express GAD65. In agreement with this freshly isolated rat islets express more GAD67 mRNA than GAD65 mRNA [27].

The expression of GAD65 is dependent on the metabolic state of the cell, as the percentage of GAD65-positive cells increases with glucose concentration. This dependence is further shown by the reversibility of the process; when cells were cultured in $11.6 \mathrm{mmol} / \mathrm{l}$ glucose for 2 days and sequentially changed to $2.5 \mathrm{mmol} / \mathrm{l}$ glucose, GAD65 expression decreased by $30 \%$.

Similar results have been obtained in rat and human islets [10, 28], where GAD65 synthesis is strongly stimulated at high glucose concentrations in the culture media, suggesting that an enhanced function of human islet cells increases expression of GAD65.

In contrast, another study reports that in rat pancreatic islets, after 3 days in culture, both GAD isoforms increase with increasing glucose concentration [10]. That study did not, however measure GAD67 in fresh islets, and differences could be due to an increase in GAD67 expression by other islet cell types, as has been described [29]. In fresh cells, we observed that $13 \%$ of GAD67 positive-cells are negative for insulin. We do not know if glucose could regulate GAD67 expression in such cells because they are lost with increased time in culture.

The enhanced function of beta cells could be important for GAD65 expression in rat islets, since in dbcAMP-treated beta cells, which have the highest insulin secretory-rate [19], the percentage of GAD65-positive beta cells increases to $84 \%$. Note that NGF treatment also increases the percentage of GAD65-positive beta cells to $73 \%$, because this kind of treatment preserves the capability of single beta cells to discriminate between different glucose concentrations, a property lost in control cells with 
time in culture. In agreement with these results, it has been observed that primary cultures gradually lose their ability to produce insulin and this inability is accompanied by the loss of GAD65 expression [28]. It is therefore possible that GAD65 expression is related to the capability of beta cells to secrete insulin [30].

Nearly $70 \%$ of the insulin-secreting cells are GAD65-positive. In contrast, in the beta-cell subpopulation that does not secrete enough insulin to be detected by the RHPA, only $11 \%$ of them are GAD65-positive. We can assume that the latter are beta cells because we observed in the double staining experiments that all the GAD65-positive cells are beta cells, in agreement with previous observations in rat islets [29].

The expression of GAD65 has been associated with insulin expression in beta cells and it has been suggested that GAD65 could be a marker of maturity in beta-cell [28].

That $85 \%$ of the cells that present high insulin secretory rate (LP cells) express GAD65 is consistent with this idea. Large plaque-forming cells represent a beta-cell subpopulation that has reached the last stages in beta-cell maturation. These cells are responsible for most of the insulin secreted, exhibit the lowest threshold for insulin secretion in response to changes in extracellular glucose concentration and are the most suitable to be modulated by secretagogues [13, $16,17]$. Moreover, in fetal rat islets, LP cells comprise only $3 \%$ of total cells; this percentage is lower than in adult islets, where LP cells comprise roughly $50 \%$. It has been suggested that these differences could account for the lower insulin secretion observed in fetal beta cells compared with adult beta cells [31].

A higher expression of GAD65 would cause LP cells to be more susceptible to an autoimmune attack, which possibly destroys this high insulin secretoryrate subpopulation, while sparing the subpopulation with a lower secretory rate. This latter subpopulation could account for the surviving beta cells observed in the diabetic pancreas [18].

The lack of LP cells would render the islets unable to cope with increases in plasma glucose concentration and for this reason could be causally related to the development of diabetes. Therefore, understanding the regulation of GAD65 expression could be of practical importance in efforts to ameliorate the autoimmune response towards beta cells in insulin dependent diabetes mellitus.

Acknowledgements. We are very grateful to Dr. A. Tobin for donation of GAD antibodies. We also thank A. Caso for discussion and proof-reading of this manuscript.

This work was supported by the grants IN208295 from General Office of Academic Affairs, National Autonomous University of Mexico(DGAPA, UNAM) and by Miguel Aleman Foundation.

R. Vidaltamayo and M.E. Larrieta were supported by scholarships from DGAPA, UNAM and National Council of Science and Technology CONACYT, Mexico.

\section{References}

1. Sorenson RL Garry DG, Brelje, TC (1991) Structural and functional considerations of GABA in islets of Langerhans. Diabetes 40: 1365-1374

2. Karlsen AE, Petersen JS, Hagopian WA et al. (1994) Islet cell expression and autoimmunity to two isoforms of glutamic acid decarboxylase in relation to insulin-dependent diabetes. In:PR Flatt, Lenzen S (eds) Insulin secretion and pancreatic B-cell research. Smith-Gordon,UK, pp 499-507

3. Erlander MG, Tillakaratne NJ, Feldblum S, Ratel N, Tobin AJ (1991) Two genes encode distinct glutamate decarboxylases. Neuron 7: 91-100

4. Christagau S, Schierbeck H, Aanstoot HJ et al. (1991) Pancreatic B-cells express two forms of glutamic acid decarboxylase, a $65-\mathrm{kDa}$ hydrophilic form and a 64-kDa amphiphilic form which can be both membrane-bound and soluble. J Biol Chem 266: 21257-21264

5. Baekkeskov S, Aanstoot HJ, Christagau S et al. (1990) Identification of a $64 \mathrm{~K}$ autoantigen in insulin-dependent diabetes as the GABA-synthesizing enzyme glutamic acid decarboxylase. Nature 347: 151-156

6. Solimena M, De Camilli P (1991) Autoimmunity to glutamic acid decarboxylase (GAD) in Stiff-Man syndrome and insulin-dependent diabetes mellitus. Trends Neurosci 14: 452-457

7. Jaeger C, Allendörfer J, Hatziagelaki E et al. (1997) Persistent GAD 65 antibodies in longstanding IDDM are not associated with residual beta-cell function, neuropathy or HLA-DR status. Horm Metab Res 29: 510-515

8. Gaskins RH, Baldeón ME, Selassie L, Beverly JL (1995) Glucose modulates $\gamma$-aminobutyric acid release from pancreatic $\beta$ TC6. J Biol Chem 270: 30286-30289

9. Smismans A, Schuit F, Pipeleers D (1997) Nutrient regulation of gamma-aminobutyric acid release from islet beta cells. Diabetologia 40: 1411-1415

10. Katoh J, Taniguchi H, Kasuga M (1995) Response of glutamic acid decarboxylase to glucose but not arginine in islets. Life Sci 21: 1799-1805

11. Hao W, Li L, Mehta V, Lernmark A, Palmer J (1994) Functional state of the cell affects expression of both forms of glutamic acid decarboxylase. Pancreas 9: 558-562

12. Pipeleers D (1987) The biosociology of pancreatic $\beta$-cells. Diabetologia 30: 277-291

13. Hiriart M, Ramirez-Medeles MC (1991) Functional subpopulations of individual pancreatic B-cells in culture. Endocrinology 128: 3193-3198

14. Van Schravendijk CFH, Kikiens R, Pipeleers D (1992) Pancreatic $\beta$ cell heterogeneity in glucose-induced insulin secretion. J Biol Chem 267: 21344-21348

15. Heimberg H, De Vos A, Vandercammen A et al. (1993) Heterogeneity in glucose sensitivity among pancreatic $\beta$ cells is correlated to differences in glucose phosphorylation rather than glucose transport. EMBO J 12: 2873-2879

16. Hiriart M, Ramirez-Medeles MC (1993) Muscarinic modulation of insulin secretion by single pancreatic B-cells. Mol Cell Endocrinol 93: 63-69

17. Hiriart M, Sánchez Soto C, Ramírez-Medeles MC, Malaisse W (1995) Functional heterogeneity of single pancreatic beta cells stimulated by L-leucine and the methyl ester of succinic or glutamic acid. Biochem Mol Med 54: 133-137

18. Pipeleers D, Ling Z (1992) Pancreatic beta cells in insulindependent diabetes. Diabetes Metab Rev 8: 209-227

19. Vidaltamayo R, Sánchez-Soto C, Rosenbaum T et al. (1996) Neuron-like phenotypic changes in pancreatic beta cells induced by NGF, FGF and dbcAMP. Endocrine 4: 19-26 
20. Frödin M, Sekine N, Roche E et al. (1995) Glucose, other secretagogues, and nerve growth factor stimulate mitogenactivated protein kinase in the insulin-secreting $\beta$ cell line INS-1. J Biol Chem 270: 7882-7889

21. Rosenbaum T, Vidaltamayo R, Sánchez-Soto C, Zentella A, Hiriart M (1998) Pancreatic $\beta$ cells synthesize and secrete nerve growth factor. Proc Natl Acad Sci USA 95: 7784-7788

22. Kaufman DL, Houser CR, Tobin AJ (1991) Two forms of the $\gamma$-aminobutyric acid synthetic enzyme glutamate decarboxylase have distinct intraneuronal distributions and cofactor interactions. J Neurochem 56: 720-723

23. Chang YC, Gottlieb DI (1988) Characterization of the proteins purified with monoclonal antibodies to glutamic acid decarboxylase. J Neurosci 8: 2123-2130

24. Neill JD, Frawley LS (1983) Detection of hormone release from individual cells in mixed populations using a reverse hemolytic plaque assay. Endocrinology 112: 1135-1137

25. Hiriart M, Matteson DR (1988) Na channels and two types of Ca channels in rat pancreatic B-cells identified with the reverse hemolytic plaque assay. J Gen Physiol 91: 617-639
26. Jorns A (1994) Immunocytochemical and ultrastructural heterogeneities of normal and glibenclamide stimulated pancreatic beta cells in the rat. Virchows Arch 425: 305-313

27. Faulker-Jones B, Cram DS, Kun J, Harrison LC (1993) Localization and quantitation of expression of two glutamate decarboxylase genes in pancreatic beta cells and other peripheral tissues of mouse and rat. Endocrinology 133: 2962-2972

28. Bjork E, Kampe O, Karlsson FA et al. (1992) Glucose regulation of the autoantigen GAD65 in human pancreatic islets. J Clin Endocrinol Metab 75: 1574-1576

29. Petersen JS, Russel S, Marshal MO et al. (1993) Differential expression of glutamic acid decarboxylase in rat and human islets. Diabetes 42: 484-495

30. Degli Espositi M, Mackay IR (1997) The GABA network and the pathogenesis of IDDM. Diabetologia 40: 352-356

31. Hiriart M, Martínez-Merlos MT, Ramírez-Medeles MC (1997) Physiological behaviour of functional subpopulations of single pancreatic $\beta$ cells. Adv Exp Med Biol 426: 267-274 